17 Hanson DL, Horsburgh CR, Fann SA, Havlik JA, Thompson SE. Survival prognosis of HIV infected patients. $\mathcal{F}$ Acquir Immune Defic Syndr 1993;6:624-9.

18 Masur H, Ognibene FP, Yarchoan R, Stelhamer JH, Baird $\mathrm{BF}$, Travis $\mathrm{E}$, et al. CD4 counts as predictors of opportunistic pneumonias in human immunodeficiency virus (HIV) infection. Ann Intern Med 1989;111:223-31.

19 Neaton JD, Wentworth DN, Rhame F, Hogan C, Abrams DI, Deyton L for the Terry Beirn Community Programs for Clinical research on AIDS (CPCRA). Methods of studying interventions: considerations in choice of clinical endpoint for AIDS trials. Stat Med 1994;13: 2107-25.

20 Choi S, Lagakos SW, Schooley RT, Volberding PA. CD4 ${ }^{+}$ lymphocytes are an incomplete surrogate marker for clinical disease progression in persons with asymptomatic HIV infection taking zidovudine. Ann Intern Med 1993, 118:674-80

21 Lin D, Fischl MA, Schoenfeld D. Evaluating the role of CD4-lymphocyte counts as surrogate endpoints in human immunodeficiency virus clinical trials. Stat Med 1993;12:835-42.

22 Levy JA, Ramachandran B, Barker E, Guthrie J, Elbeik T. Plasma viral load. $\mathrm{CD4}^{+}$lymphocyte counts and HIV-1 production by cells. Science $1996 ; 271: 670-1$.

23 Kelleher AD, Carr A, Zaunders J, Cooper DA. Alterations in the immune response of human immunodeficiency virus (HIV)-infected subjects treated with an HIV-specific protease inhibitor, Ritonavir. F Infect Dis 1996;173 321-9.

24 Ho DD, Neumann AU, Perelson AS, Chen W, Leonard JM, Markowitz M. Rapid turnover of plasma virions and CD4 lymphocytes in HIV-1 infection. Nature 1995;373: 123-6.
25 Wei X, Ghosh SK, Taylor ME, Johnson VA, Emini EA, Deutsch $\mathrm{P}$, et al. Viral dynamics in human immunodeficiency virus type 1 infection. Nature 1995;373:117-22.

26 Liuzzi G, Chiriani A, Clementi M, Bagnarelli P, Valenza A Cataldo PT, Piazza M. Analysis of HIV-1 load in blood, semen, and saliva: evidence for different viral compartments in a cross-sectional and longitudinal study. AIDS 1996;10:F51-6.

27 Lafeuillade A, Djediouane A, Poggi C, Profizi N, Costes O, Tamalet C. Kinetics of viral clearance in plasma, peripheral blood mononulear cells and lymph nodes. AIDS $\mathbb{D}$ 1996;10:801-2.

28 Yerly S, Kaiser L, Mermillod B, Baumberger C, Hirschel B, Perrin L. Response of HIV RNA to didanosine as a B, Perrin L. Response of HIV RNA to didanosine

29 Coombs RW, Welles SL, Hooper C, Reichenfelder PS, D'Aquilla RT, Japour AJ, et al. Association of plasma $\mathbb{D}$ human immunodeficiency virus type 1 RNA level with? risk of clinical progression in patients with advanced

30 Phillips AN, Eron J, Bartlett JA, Rubin M, Johnson J, Price $S$, et al. HIV-1 RNA levels and the development of clinical disease. AIDS 1996;10:859-65.

31 Saag MS, Holodniy M, Kuritzkes DR, O'Brien WA, Coombs R, Poscher ME, et al. HIV viral load markers in clinical practice. Nature Med 1996;2:625-9.

32 Staprans SI, Hamilton BL, Follansbee SE, Elbeik $T, 8$ Barbosa P, Grant RM, Feinberg MB. Activation of virus replication after vaccination of HIV-infected individuals. $\mathcal{F} \vec{\circ}$ Exp Med 1995;182:1727-37

33 Donavon RM, Bush CE, Markowitz NP, Baxa DM, Saravolatz LD. Changes in virus load markers during AIDS-associated opportunistic diseases in HIV-infected $\omega$ persons. F Infect Dis 1996;174:401-3.

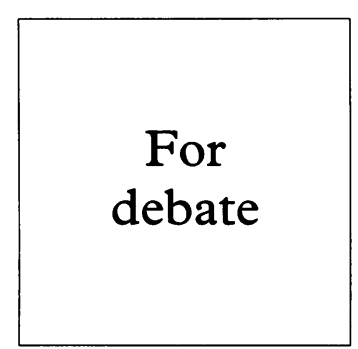

Nuffield Department of Medicine, Level 7 John Radcliffe Hospital, Headington, Oxford OX3 9DU T Peto

Accepted for publication 25 March 1997

\title{
Viral load-not yet the holy grail
}

\author{
Tim Peto
}

\section{Introduction}

There are now nine effective antiviral drugs generally available and their numbers are rapidly increasing. The number of different drug combinations is rising even more rapidly. For example, with only the nine drugs there are 36 two drug and 84 three drug combinations available. With the possibility of switching from one combination to a second combination, patients face the bewildering possibility of over 10000 different regimens even before a second switch of combination is considered.

The advantages of viral load testing This therapeutic uncertainty means that the clinician is turning to the virologist for help and the recent development of quantitative tests for measurement of circulating plasma HIV RNA (qRNA) appears to offer many advantages. The test has been shown to be repeatable within $0.3 \mathrm{log}$ units as long as the blood sample is processed rapidly or stored at $-70^{\circ} \mathrm{C}$. Retrospective studies have shown that qRNA appears to be a good prognostic marker, especially in patients with high CD4 counts, ${ }^{12}$ and also appears to give a good indication for perinatal infectivity. Patients have a large range of results from $<5000$ copies to over 1000000 copies. Because of the inaccuracies of the technique, it is preferable to refer $\stackrel{5}{=}$ to $\log$ units (for the values above the log unit equivalents are $<3.3$ to $>6$ ). The DELTA study, ${ }^{3}$ coordinated by the Medical Research $\ni$ Council, is looking at about 13000 viral loado tests and CD4 counts in about 2000 patients and will relate the results to clinical event $\stackrel{0}{=}$ rates. It is tempting to assume that $\mathrm{CD} 4$ counts will be a good marker of the degree of disease progression while the level of qRNA will be associated with the disease activity and $\omega$ therefore future disease progression.

qRNA has also been used to monitor short $\stackrel{\circ}{\circ}$ term changes in viral load following drug treatment. Zidovudine reduces plasma viral 0 load RNA by about $0.3 \log$ units and two drug combinations of reverse transcriptase $\stackrel{\square}{\square}$ inhibitors reduce viral load by up to $1.8 \log \Phi$ units. However, the largest changes have been seen in triple therapy regimens which include 8 HIV protease inhibitors. These combinations reduce qRNA by about $2.0 \log$ units and in some cases qRNA falls to below the "limit of" detection", which ranges from 10000 copies $(4.0 \mathrm{log}$ units) to 20 copies $(1.3 \mathrm{log}$ units), according to the assay. The present enthusiasm for protease inhibitors depends much on the dramatic effect that these drugs have on the viral load. 
Problems with the interpretation of viral load

How then, should we interpret these changes? Unfortunately, we have little data to help us. Retrospective surveys show that qRNA is a good prognostic marker. However, any drug or treatment induced changes in prognostic markers should not be used to infer that these changes will be translated into clinical efficacy. The experience from other medical conditions (for instance, cardiac disease, cancer, osteoporosis) has shown that the use of surrogate markers can often give misleading and even frankly wrong conclusions. Our experience from HIV to date is no better. It appears from preliminary virological results from the DELTA and Concorde trials that, like CD4 count changes, small reductions (about $0.3 \mathrm{log}$ units) in qRNA are not translated into clinical benefit while somewhat larger but transient falls $(1.8$ $\log$ units peaking at 8 weeks and falling back to baseline within 96 weeks) are related to clinical benefit lasting for more than 2 to 3 years. The larger falls in viral load seen with the protease inhibitors are related to larger rises (about 100 $\left.\times 10^{6} / 1\right)$ in CD4 counts and anecdotal accounts of patient reported increases in "wellbeing". However, the duration of these benefits is not yet known nor has the effect on survival been shown to be appreciably better than that caused by the combination of zidovudine and didanosine.

The case for qRNA as a prognostic marker is therefore essentially based on its advantages as a prognostic marker, its pathophysiological attractiveness, and on the large changes in plasma viral load produced by the protease inhibitors which appear to be associated with large increases in CD4 counts. However, there are some major gaps in our knowledge which need to be filled before measurement of plasma viral load can be used reliably by clinicians. Some unanswered questions about the interpretation of viral load are discussed below.

ARE ALL HIV STRAINS DETECTED IN THE ASSAY? Some viral types commonly found outside North America may not be reliably detected. ${ }^{4}$ It is also possible that one effect of treatment is to distort the assay either by creating avirulent virions which are still detected by the assay or virulent virions which escape detection.

\section{IS CIRCULATING VIRAL LOAD IDENTICAL WITH DISEASE ACTIVITY?}

The pathophysiological basis for "disease activity" is still unknown. Although there is evidence that circulating viral load is correlated with disease activity, it is equally possible that viruses replicating in fixed tissues is the key driving force of the disease and can only be assayed by relevant tissues biopsies. ${ }^{5}$

CAN WE INTERPRET STEADY STATE VIRAL LOAD LEVELS FOR INDIVIDUALS?

Most of the data available are correlating groups of viral load results with outcomes. ${ }^{126}$ Much more detailed cohort data are required from randomised clinical trials before reliable guidelines on "safe" or "dangerous" levels of viral load can be established. It is unclear how many patients tolerate prolonged high viral loads well or how many progress early in spite of low viral loads. The interpretation of viral loads in conjunction with serial CD4 counts has not yet been fully evaluated.

WHAT IS THE RELATION BETWEEN VIRAL LOAD CHANGES AND CLINICAL BENEFIT?

Existing knowledge is based on the pooled data from clinical trials. The DELTA trial virology substudy suggests that the effect of only a transient fall in viral load can produce a much more lasting clinical benefit. However, before individual viral load changes can be reliably interpreted, much more information is needed from the serial viral load estimations of many thousands of patients over many years. It is possible that patients who fail to have a fall in viral load may still obtain a clinical benefit from the drug.

\section{CAN WE MEASURE DRUG RESISTANCE?}

At present there is no reliable assay for detecting clinical viral resistance. It is unclear whether a rising viral load (or falling CD4 count) in the face of continuing treatment represents true viral resistance to the drug or simply a drug induced change in the distribution of virions (or $\mathrm{CD} 4$ cells) within the patient.

\section{Clinical role of viral load testing}

Individual patient monitoring of viral load appears to be scientifically rational and is clinically attractive because it provides the clinician with an early indication of disease progression, drug response, and drug failure and therefore provides some form of order in an environment of therapeutic confusion. The effect of using viral load, rather than depending simply on clinical signs and CD4 counts, is to encourage clinicians to start antiviral treatment earlier and to switch combinations earlier. It is possible that some patients will run out of effective drug combinations before they develop symptomatic disease.

Unfortunately there is no evidence that the use of viral load testing improves clinical outcome. Although a reduction in viral load is associated with increased survival over several months, most patients starting on drug treatment expect to survive for much more than a few months. There is clinical uncertainty as to whether the early or late treatment of high viral load produces greater clinical benefit and survival over a period of at least 3 to 5 years. It would be an immense tragedy if the use of oversensitive viral load testing lured clinicians into squandering valuable anti-HIV drugs on otherwise clinically stable patients allowing them to develop drug resistance or alternatively switching patients away from clinically effective drug combinations simply because of a rising viral load.

1 O'Brien WA, Hartigan PM, Martin D, Esinhart J, Hill A, Benoit S, et al. Changes in plasma HIV-1 RNA and CD lymphocyte counts and the risk of progression to AIDS N Engl F Med 1996;334:426-31.

2 Mellors JW, Rinaldo CR, Gupta P, White RM, Todd JA, 
Kingsley LA. Prognosis in HIV-1 infection predicted by the quantity of virus in plasma. Science 1996;272: 1167-70.

3 DELTA Co-ordinating Committee. DELTA: a randomised double-blind controlled trial comparing combinations of zidovudine plus didanosine or zalcitabine with zidovudine alone in HIV infected individuals. Lancet zidovudine alone

4 Dunne AL, Crowe SM. Comparison of branched DNA and reverse transcriptase polymerase chain reaction for quantifying six different HIV-1 subtypes in plasma. AIDS 1997;11:126-7.

5 Lafeuillade A, Tamalet C, Popggi C, Pellegrino P, Tourres C, Izoper J. Anti-retroviral effect of zidovudine-didanosine combination on blood and lymph nodes. AIDS sine combination

6 Ruiz L, Romeu J, Clotet B, Balague M, Cabrera C, Sirera G, et al. Quantitative HIV-1 RNA as a marker of clinical stability and survival in a cohort of 302 patients with a mean CD4 cell count of $300 \times 10^{\circ} / 1$. AIDS 1996;10:F39-44. 